\title{
Ethical Consumer Perceived Value in Sustaining Recycling Behaviour
}

Noorasikin M.M. ${ }^{a}$, Maisarah, Ahmad $^{b}$, Mashitoh, Y. ${ }^{\mathrm{c}} \&$ Khairul Akmaliah, A. ${ }^{a}$

${ }^{a}$ Graduate School of Business, Universiti Kebangsaan Malaysia, 43600 Bangi, Selangor, Malaysia.

${ }^{b}$ Faculty of Economics and Management, Universiti Kebangsaan Malaysia, 43600 Bangi, Selangor, Malaysia.

'Institut Islam Hadhari, Universiti Kebangsaan Malaysia, 43600 Bangi, Selangor,

Malaysia.

Email: sara@ukm.edu.my

\section{Abstract}

Recycling has imparted meaningful experience and perceived value from individual's recycling activities. Consumer perceived value (CPV) is important in defining consumers' experience that connects with one's goals, inclinations and mental models; perceived valuable and beneficial, thus motivate sustainable behavior. This study sought to understand how ethical consumer perceived value (ECPV) influences the sustaining of recycling behavior. Nine interviews were conducted at The Federal Territory of Putrajaya for this interpretive study. It identifies two taxonomies of ethical perceived value (EPV) in individual's sustainable recycling experience. First, ethically desirable value (EDV) taxonomy (six drivers), second, spiritual/religious value taxonomy (three drivers). This paper concludes with the value-map taxonomy of ECPV on Recycling to guide in mapping a strategic social marketing practice in Malaysia's government policy to motivate good social conduct among individual and society.

Keywords: Recycling behavior; consumer perceived value; ethical percieved value; spiritual/religious perceived value, marketing. 


\section{Introduction}

Recycling activities have been referred as important mechanisms in curbing solid waste problems by incorporating 3R concept 'reduce, reuse and recycle'. Recycling behaviour studies have traditionally been focused on inducing behavioural change among individuals (Osbaldiston and Schott, 2012; Bamberg and Moser, 2007, Halvorsen, 2012, Tang et. al, 2011). There are significant empirical evidences correlating recycling behaviors with altruistic values on the environment (Stern and Dietz, 1994; Stern, 2000, 2005; Dietz, 2005; Schultz and Zelezny, 1999; Shultz, 2001; Thompson and Barton, 1994; Nordlund and Garvill, 2002; Chawla, 1999; Milfont and Duckit, 2010, Saphores et. al, 2012). Altruistic values emphasize on feeling of concern and civic duty to other people, which triggers one's responsibility to protect the environment. Altruistic values are arrayed from the perspective of personal moral norms in motivating and influencing individual's engagement for environmental behaviour (Prestin and Pearce 2010; Saphores et al. 2012; Guerin et al. 2001; Tang et al. 2010; Barr, 2007; Torgler et al. 2008).

Although recycling behaviour studies have successfully explained on altruistic values in inducing recycling behaviour, mostly are from western societies. Therefore, exploration from local perspective is needed, specifically, among Muslims in Putrajaya, Malaysia. As emphasized by Stern and Dietz (1994) "value orientations are not mutually exclusive; that individuals may hold several orientations to some degree; and that value orientations may vary across individuals, social-structural groups, and cultures".

Furthermore, the knowledge on how perceived value sustains recycling behaviour remains deficient. Most environmental value studies were on triggers of behaviour but less on what sustain recycling behaviour. Value-Beliefs-Norms Theory of Environmental Behaviour, Norms Activation Model, Theory of Planned Behaviour, and several others are frequently applied in explaining the behaviour. This study seeks to understand how EPV is interpreted in recycling activities and influences the sustaining of recycling behaviour. 
Additionally, there is limited exploration on ethical values from spiritual and religious perspective. In Islam, religion is 'a way of life' and inseparable from human's day-to-day life. Human's role as 'Khalifah' obliged them to serve their responsibility and relationship to Allah and other mankind. Therefore, mankind holds trusteeship (amanah) on the blessed of nature by Allah. The trusteeship on nature imposed a moral responsibility in every human to maintain good care and do no harm (al zarar) to the environment, to act in moderation and be accountable for any action that may invite destruction of nature (Ozdemir, 2003; Khalid, 2002; Ahmad, 2009; Baharuddin, 2012; Mortazavi, 2004). What is given should be preserved and inherited. Furthermore, Islam forbids extravagance. Although, there are isolated attempts made to explore the association of religious beliefs with recycling behaviour (Mohamad et. al, 2011, 2012; Mashitoh 2009), little is known about how religious element is interpreted in individuals' recycling experience in the Asian context.

\section{Conceptual Perspectives}

Sustainable recycling behaviour will be realized through what consumer perceived as satisfying recycling experience (SRE). Therefore, SRE marks the importance of designing effective interventions, consistent with what consumers perceive as valuable and beneficial.

$\mathrm{CPV}$ is originated from marketing principles and derived from interaction between consumers and their experiences from participating in recycling intervention program by Perbadanan Putrajaya. The interaction between subject (recyclers) and object (incentivebased recycling experience) will induce what recyclers perceived as valuable or beneficial. It depends on their preference of pro and contra in CPV and it varies between individual. $\mathrm{CPV}$ is believed to be an important tool to motivate sustainable recycling behaviour. 
Holbrook $(1999,2006)$ defined CPV as "an interactive relativistic preference experience" that is intimately interrelated, but "independent or mutually exclusive". CPV is further defined as "an outcome of evaluative judgement" that involves an interaction between consumer (subject) and products, services, social services or other experiences(objects). Based on that, recyclers' interaction with their experiences are expected to generate a perceived value that is cognitive (extrinsic) and affective (intrinsic) and the value is either oriented towards self, other human or non-human. The extrinsic value refers to external, tangible, utilitarian and functional benefit or value that one perceived from their experience (Holbrook, 1999; Woodall, 2003; Ziethaml, 1988). Meanwhile, intrinsic value is the perceived internal appreciation "appreciated as an end in itself" for the experience. Self-oriented and other-oriented value represents the perceived value that served one's interest for themselves, other people or things.

CPV focuses on 'exchange' (beneficial and valuable), thus motivates to sustain the behaviour. Many regard it as similar to human values. However, there are connections on how intrinsic aspects of human beliefs and values may influence CPV.

CPV emphasized the process of exchange toward a directed goal, that is a "trade-off of salient give and get components" (Ziethaml, 1988). "Consumer value involves a trade-off between what consumer receives and what she gives" (Woodruff, 1997), and the elements of "benefits and sacrifices" (Woodall, 2003). In contrast, values as explained by Rokeach (1973) is a desirable end goal "terminal value" that humans aim to achieve through the means and guidelines "instrumental values" for achieving the goals. According to Schwarts (2012), 'values' are beliefs, desirable goals, which transcend specific actions and situations. Therefore, the relative importance of human values guided actions and applied as a basis of individual's preferential judgement and perceived value.

Holbrook (1999) presented typologies of consumer value, a more diverse and complex axiological concept or perceived value. Consistent with Holbrook's typologies, recycling experience is predicted to generate multi-dimensional recycling perceived value; which is organized within two key distinctions of intrinsic and extrinsic, and self-oriented and others-oriented. Although, Holbrook's $(1999 ; 2006)$ typologies of perceived value are 
captured under four main categories: economic value; social value; hedonistic value; and ethical value. This study will only concentrate on the EPV categories emphasizing on i) ethics and ii) spiritual wisdom. This is consistent with numerous major findings of environmental behaviour studies whereby altruistic and biospheric elements are the main drivers.

EPV is defined from i) ethical wisdom results from virtue, justice and morality; ii) spiritual value relates to faith, ecstasy, sacredness and magic (Holbrook, 1996, 1999, 2006). EPV emerged from the experience 'self justifying and end in itself'. The experience generates ethical sense of satisfaction through the feelings of concern, devotion or spiritual ecstasy. Besides Holbrook, Sheth et. al (1991) coined the term 'emotional value' which associated to a broader perspective of emotions, that is intrinsic or aesthetic in nature. 'Ethical' perspective falls under 'emotional value' in Sheth et. al's (1991) concept of CPV of consumption experience.

The gap between ECPV and altruistic environmental values leads the exploration of individual recycling behaviours from 'inside-out' marketing perspective, particularly in discovering recycler's EPV from their direct involvement and experience in recycling programs. Understanding recycler's EPV would help to explain the elements that satisfy and sustain recycling behaviour and is parallel with the importance of social marketing in promoting sustainable behaviour. The ultimate aim is to design interventions; thus, induces satisfying perceived value, which promotes continuous commitment and action toward sustainable behaviour (De Young, 2011, 2013).

The figure below represents a theoretical model on how ECPV is derived from recycling experience in Putrajaya: 


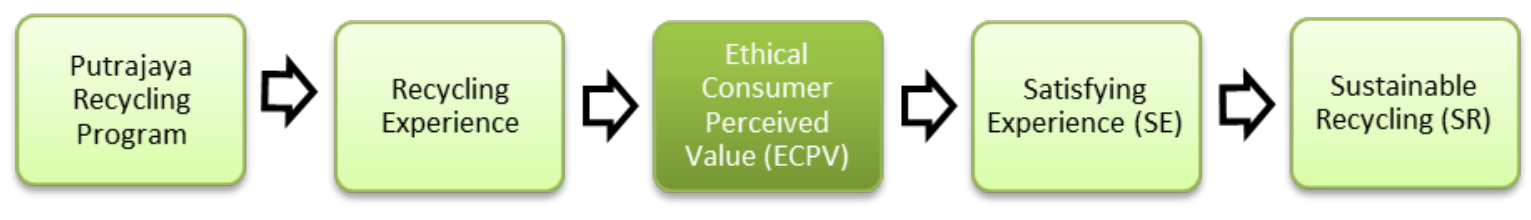

Figure 1: Theoretical Model for ECPV of Sustainable Recycling adapted from Holbrook, 1999; Gallarza et. al, 2011; De Young 1986.

Evidently, ECPV is influencing social marketers' understanding to motivate and sustain social change. The failure to understand $\mathrm{CPV}$, results in financial waste and indirectly dampen the ultimate aim.

\section{Research Questions and Study Objective}

\subsection{Grand Research Question}

What are the ethical perceived values that influence sustainable recycling behaviour?

\subsection{Study Objective}

The objective of this study is to understand a recycler's experience in translating their EPV into a sustainable recycling behaviour.

\subsection{Guiding Questions}

The guiding questions for this study are:

a) How ethical perceived value is interpreted in recycling activities?

b) What are the ethical perceived values that influence recycling experience?

c) How do ethical perceived values influence the sustaining of recycling behaviour? 


\section{Study Area - Putrajaya}

In 2004, Putrajaya jump-started a recycling project for a recycling national model and aimed for sustainable environment. The pilot project was launched (as shown in Figure 2) and offers three types of programs. First is 'waste wise' program for recycling activities in industrial, commercial areas and government offices around Putrajaya territory. Second is community program which involves Buy Back Centre (BBC) at Precint 8 and 9; curbside recycling and cage recycling. Third is designed for kindergarten, primary and secondary schools in Putrajaya.
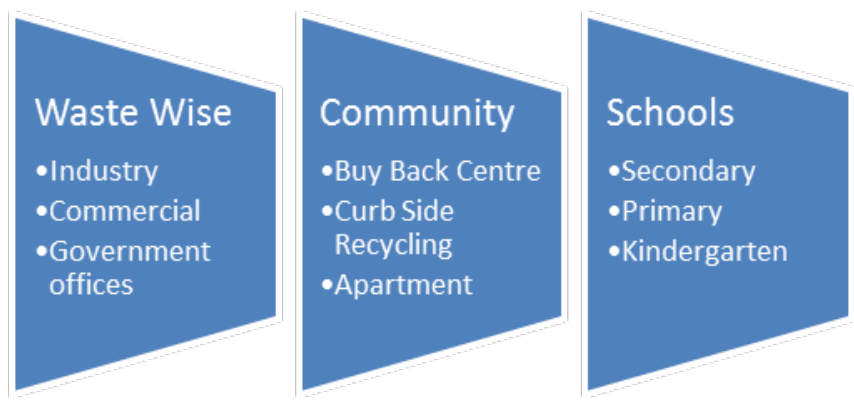

Figure 2: Recycling Programs in Puttrajaya

Since 2004, Putrajaya leads Kuala Lumpur, Selangor and Pahang in recycling project (NST, 2012) and also the pioneer Green City of Malaysia.

\section{Methods}

This study focused on BBC recycling programs. Informants (all Muslims) were purposely selected among recyclers at BBC, Precint 9, Putrajaya. The semi-structured interview was adopted and took forty minutes to one hour. The content is based on the guidelines below: 
Interview Guides: The Ethical Consumer Perceived Value in Sustaining Recycling Behaviour

1. Could you share your recycling experience in Putrajaya?

2. Could you share your recycling experience prior to living in Putrajaya?

3. Why do you recycle?

4. What satisfies you most in your recycling venture?

- Describe one situation about recycling that you like most.

- Describe a situation which you dislike.

5. What would be the most important motivation for you to continue doing your recycling activities?

6. What do you think are the challenges that would prevent you from recycling?

7. Could you describe the experience that triggers you to pursue recycling as your new behaviour and continue making it as your routine/compulsory activity? (Avid recyclers)

8. Some people would say that recycling has got very little impact on environment. Do you agree?***

9. Do you find your religious belief to be associated with your recycling activities?***

*** Additional probing question - If necessary

During the interview, respondents explained on their recycling experience. Next, they were asked several specific questions and were probed to elicit better understanding. All interviews were transcribed verbatim. 
9 interviews were conducted and selected. Their basic demographic information and years of recycling experience are shown in Table 1 below.

\begin{tabular}{|c|c|c|c|}
\hline Informants & Age & Profession & Recycling experience \\
\hline Informant 1 & $20 \mathrm{~s}$ & Teacher & $\begin{array}{l}>2 \text { yrs }(\mathrm{BBC} \text { and } \\
\text { kerbsite) }\end{array}$ \\
\hline Informant 2 & $40 \mathrm{~s}$ & $\begin{array}{l}\text { Clerk }- \text { Federal } \\
\text { government office }\end{array}$ & $\begin{array}{l}>2 \text { yrs }(\mathrm{BBC} \text { and } \\
\text { wastewise) }\end{array}$ \\
\hline Informant 3 & $20 \mathrm{~s}$ & $\begin{array}{l}\text { Contract staff - } \\
\text { Federal } \\
\text { government office }\end{array}$ & $\begin{array}{l}3 \text { mths }(\mathrm{BBC}) \\
\text { More than } 6 \text { years in } \\
\text { other places }\end{array}$ \\
\hline Informant 4 & $40 \mathrm{~s}$ & Housewife & $\begin{array}{l}>2 \text { years } \\
(\mathrm{BBC}+\text { kerbsite }) \\
\text { About } 10 \text { yrs in other } \\
\text { places }\end{array}$ \\
\hline Informant 5 & $50 \mathrm{~s}$ & Teacher & $\begin{array}{l}\text { About } 1 \text { year }(\mathrm{BBC}+ \\
\text { kerbsite) }\end{array}$ \\
\hline Informant 6 & $20 \mathrm{~s}$ & Self Employed & About 1 year (BBC) \\
\hline Informant 7 & $50 \mathrm{~s}$ & Volunteer & $\begin{array}{l}>2 \text { yrs }(\mathrm{BBC}) \\
\text { Total more than } 10 \mathrm{yrs}\end{array}$ \\
\hline Informant 8 & $60 \mathrm{~s}$ & Retiree & $\begin{array}{l}>4 \text { yrs } \\
\text { Total more than } 10 \text { years }\end{array}$ \\
\hline Informant 9 & $30 \mathrm{~s}$ & Clerk & $\begin{array}{l}>4 \text { yrs }(\mathrm{BBC}) \\
\text { Total more than } 10 \text { years }\end{array}$ \\
\hline
\end{tabular}

Table 1 : Recycling experience of 9 informants

Classification, interpretation, coding and thematic analysis were conducted by applying Atlas.ti, qualitative data analysis software. Lastly, the output is presented in a table format and designed network map using Visual Understanding Environment (VUE) software for better presentation and interpretation.

\section{Findings and Analysis}

\subsection{Individual's Ethical Perceived Value (EPV) from Recycling Experience in Putrajaya}

EPV is discussed under two broad taxonomies of a) Ethically desirable value (EDV); b) spiritual/ Islamic religious value. EPV map reflected the connecting attributes between both value taxonomies, whilst another map translated the reflection of Islamic religious 
role in the Putrajaya recycling experience. The summary of EDV and spiritual/Islamic religious value attributes is presented as in the Table 2 below:

\begin{tabular}{|l|l|}
\hline $\begin{array}{l}\text { Ethical Perceived Value } \\
\text { (EPV) }\end{array}$ & \multicolumn{1}{|c|}{ Attributes } \\
\hline $\begin{array}{l}\text { Ethically desirable value } \\
\text { (EDV) taxonomy }\end{array}$ & $\begin{array}{l}\text { Empathy for others } \\
\text { Concern for children and future generation } \\
\text { Feeling guilty for hurting nature } \\
\text { No other choice } \\
\text { Preserve nature } \\
\text { Cleanliness, health and well-being }\end{array}$ \\
\hline $\begin{array}{l}\text { Spiritual/ Islamic } \\
\text { religious value taxonomy }\end{array}$ & $\begin{array}{l}\text { Act in moderation } \\
\text { Islam and cleanliness } \\
\text { Human as Khalifah - Responsibility for environment } \\
\text { Human as Khalifah - Responsibility for other } \\
\text { mankind }\end{array}$ \\
\hline
\end{tabular}

Table 2: Summary on EPV from Recycling Experience in Putrajaya

\subsection{Ethically Desirable Value (EDV) Taxonomy}

EDV taxonomy induces good feelings and motivates sustainable recycling behaviour. First is empathy for others, consistent with Schwartz's (1977) norms activation theory that explains feelings and moral obligation as the fundamentals in driving altruistic values. Informants 1 and 9 shared their deep empathy for others, whereby recycling helps them to serve their altruistic value.

R1 - There was a time when Alam Flora staff has to clean up the broken glass from my waste bin. I felt so guilty seeing him doing it.

R1 - I was touched when Alam Flora staff has to take the hassle of separating my waste. I shouldn't have allowed that to happen. It's not fair for him.

R1 - When we look at the cleaners or garbage men, we should be more sensitive. We should help them indirectly, to reduce their burden. 
R9 - My mom always told me to respect the street cleaners. She always got angry when I litter. "Poor the street cleaners, they are so unfortunate. We inconvenience them due to our irresponsibility", she said. That's my mom. Maybe that's also how I teach my children.

Besides the care for others, empathy is also shared through recycler's charitable behaviours. Informant 1,2 and 8 shared their experiences in donating old clothes and collecting money for charity.

R1 - Most of the clothes that we sent to recycling centre could be re-sell and re-use. We indirectly help those who can't afford to purchase expensive items.

R1 - Normally, before Hari Raya I'll bring back old clothes to the village. I collect them from friends, and my mom will distribute them to the needy. We've been doing this for a long time, since I was a kid. Now we're living in $\mathrm{KL}$, we still continue bringing back old clothes and distributing them to surau and other places.

R2 - We have a recycling corner in our office. Half of the money is distributed to our colleague. He is a leukemia patient. Sometimes, our earnings are not enough, and this is one way to help others.

$\mathrm{R} 8$ - The money received from recycling could be shared with the poor. We can donate it to orphans. This could help us to sustain our charitable efforts. Therefore, our effort will not go in vain.

Secondly, EDV is expressed through the care and concern for future generations. Present recycling behaviours are part of activities to instill positive values among younger generations. Informant 1 expressed his concern and justified the importance of recycling in nurturing good behavior in the future generations.

R1 - We recycle for our future generations. It's about instilling positive values in our children. When they are at school, they will share these values with their friends. 
Besides concern for future generations, recycling reduces one's guilt for hurting nature. Informant 4 and 6 expressed their concern of how their behaviour could affect the environment. The guilt induces their positive behaviour toward the environment.

R4- Here, I could recycle my cooking oil. Rather than throwing it away and affect our environment, we could recycle it and preserve the environment. It's a new source of energy.

R6 - I prefer clean, healthy and beautiful environment. If we don't make an effort to recycle and keep producing new (product), consume and produce again, in the end we are going to have mountains of waste. Our beautiful nature will be a nature full of waste, which in the end threatens our environment.

The study also found that informants 2,3,5 and 6 considered the actions to protect the environment as important when human are left with 'no other choice' in curbing the environmental problem.

R2 - When we see too much waste, when our landfills have to cater for mountains of waste, how do we solve this problem? I don't know how it could be solved. We just don't have a choice!

R3- We live in this world and created so much destruction. Where are we going to live?

R5 -If we don't recycle, our environment and our earth will be the landfills!

R6 - Waste will generate toxic to our river and sea. It will endanger our nature and ecosystem. If there is no marine life, what are we going to eat?

R6 - I love nature. With this global warming, Malaysia also feels the heat. What causes this to happen? If we don't take good care of our environment, Malaysia could also be as warm as the Arab countries. 
The cognition and understanding on recycling nurture the commitment to environmental and recycling activity. Informants 1, 4, 5, 6 and 7 shared their experiences.

R1 - Recycling could help me preserve the environment and show respect to the nature.

R4 - Recycling is actually more on preserving our environment. It would help in reducing consumption. For example, if we recycle plastic, it will reduce waste and promote a clean environment.

R5 - Recycling helps to protect our environment.

R7 - I have a big family, therefore we consume a lot of things. There are a lot of waste materials. Before, we just dumped them into the waste bin. After being exposed to recycling, I thought, might as well send some of these things (to the centre). It's not for the money; it's more about recycling products that can still be reproduced. In the sense that it develops reproduction and reselling of materials. It should impact the environment (positively). Now, we cut more trees, we produce new things. We should find other alternatives, we don't need to manufacture new things. We could recycle what can be recycled.

R7 - I'm a farmer, therefore the environment is very important to me, life is very important, trees are very important. Then we are concerned about taking care of the environment. So, in this particular case I say, I will continue, if I can do more, I will do more.

Lastly, recycling is also associated with cleanliness, health and well-being. Informants 1 and 4 expressed their appreciation for the maintained cleanliness and well-being in Putrajaya to be called 'home'.

R1-We hardly see litter here in Putrajaya. We are very happy with it and are excited to maintain that. Similarly, at home, when we have a clean and 
tidy home, we feel excited to continue maintaining it, making it clean, neat and beautiful.

R4 - I am satisfied with our surroundings that are clean and neat. Here, wherever we go, we could easily find waste and recycling bin. Clean and green surroundings create a peaceful mind.

Additionally, informant 4 related recycling activity to the consciousness about health and well-being, where she decided to send used cooking oil for recycling.

R4 - I only reuse cooking oil for maximum of 3 times. It's unhealthy to reuse it for many times. It could cause cancer. You know, the broken molecules. We want to serve only the best and healthy food to our children. They are the ones who like to eat fried food.

\subsection{Spiritual Value (SV) Taxonomy}

SV taxonomy emerges as part of recyclers' intention to perform ethical behaviour to earn Allah's pleasure. Majority of informants related the act of avoiding wasteful behaviour and to act in moderation as moral conducts associated with Islamic practice. Other informants associate cleanliness as part of iman (faith) in Islam. Cleanliness is translated from physical appearance and internal purification, how individual ruled their heart consistent with the guidance by Prophet Muhammed s.a.w.Informant 1, 4, 7, 8 and 9 shared their experiences.

R1- In Islam, we are obliged to maintain good relations with Allah and all His creations. Cleanliness is part of our iman.

R4 - Recycling in Islam means cleanliness. Islam also taught us to always act in moderation. That is one of the reasons why we need to recycle. 
R7 - Our religion taught us about cleanliness. It's too bad, we are the filthy one. We thought, wudu (ablution) is the only thing that Islam relates to cleanliness. Cleanliness is not just about the external hygiene, it's what's inside you. To me, that is what cleanliness means.

R9 - All of these are from within. Sometimes, people look at me when I ride my motorbike to work and collect unwanted materials. I don't steal, I don't rob other people's stuff. I do all these to gain Allah's pleasure. I want to help other people. If I'm well-off, insyaAllah (Allah-willing) I will help others. That's has always been my intention.

In Islam, every human is a Khalifah, who nurture good behaviour and maintain good relationship with the environment as part of ibadahs. Informants 7, 8 and 9 shared views on their role as Khalifah.

R7 - We cannot run away. All religions taught good values. It's (recycling and religion) interrelated. (In Islam) we are khalifahs. As khalifah, we must be a good manager. The manager is a representative of other people. Everybody is a khalifah. Me as a father, my ummah (people) is the family, my children, and then preserving the environment is part of our duty. Everything starts from there.

Apart from role as a Khalifah, informant 7 also appreciated the aesthetic value of nature and saw environment as gifts by Allah.

R7 - As I told you earlier, I'm a farmer, I would think differently. For example, when I look at the clouds, to you they're merely clouds, but to me they're more than clouds, they're a source of water. At least we are amazed with one of the wonders of God. How clouds transport water? Like us, we use water tank and transport it from one place to another. But Allah just needs to create clouds! These clouds are dispensers. The water will flow to my farm and shower all my plants. Here, mostly in urban areas, we see a lot of wasteful behaviours. We waste waters that Allah 
bestowed us. Water floods the road, it's in the drain, we pollute our river, and we fail to manage what Allah bestowed us. As a khalifah, we have a serious duty. Another thing is trees. We need to preserve, not small trees, we need to replant big trees, fruit trees are also good. Too bad, that is what our religion taught us, and yet we fail to accomplish it.

R8 - Alhamdulillah. Recycling is part of our ibadah. Even an insignificant behaviour like entering the toilet, there is a prayer to it. What more with the responsibility to maintain a clean surrounding. We can reduce production cost, example by reusing glass bottle. At home, we could reduce the usage of plastic bags, train our family to preserve the earth that Allah bestowed us, prevent diseases, clearing out stagnant water and avoid aedes.

R9 - That's how I teach my children. They are happy collecting this stuff (recyclables). I told them, if we do good things, God will reward us with good things too, because we do all this for the environment. We do it because we want to protect the environment. They will put the items in the recycling bin. Papers with papers, bottles with bottles. That's how I teach my children.

R9 - We recycle to protect the environment. Sometimes, I seem to ponder why do people litter? Why do we choose to not preserving the environment? I recalled one ustaz said in his lecture, if we have a strong faith, we will even feel guilty throwing candy wrapper on the street. If my children throw their drink packets, I'll collect and put them into my recycling bin. I wonder why do we refuse to take care of our environment? Even if they (other people) still refuse to do it, my conscience is clear. I will still do it (preserve the environment). It's a joy! 


\section{Discussion}

EPV presented various meanings of sustainable recycling experience in Putrajaya. Ethically desirable and spiritual value emerged from recycling experience offer good feeling and satisfaction to the recyclers. Map 1 summarizes the meaning of individual's EPV from recycling experience in Putrajaya.

\subsection{Ethically Desirable and Spiritual Value, the Connecting Attributes}

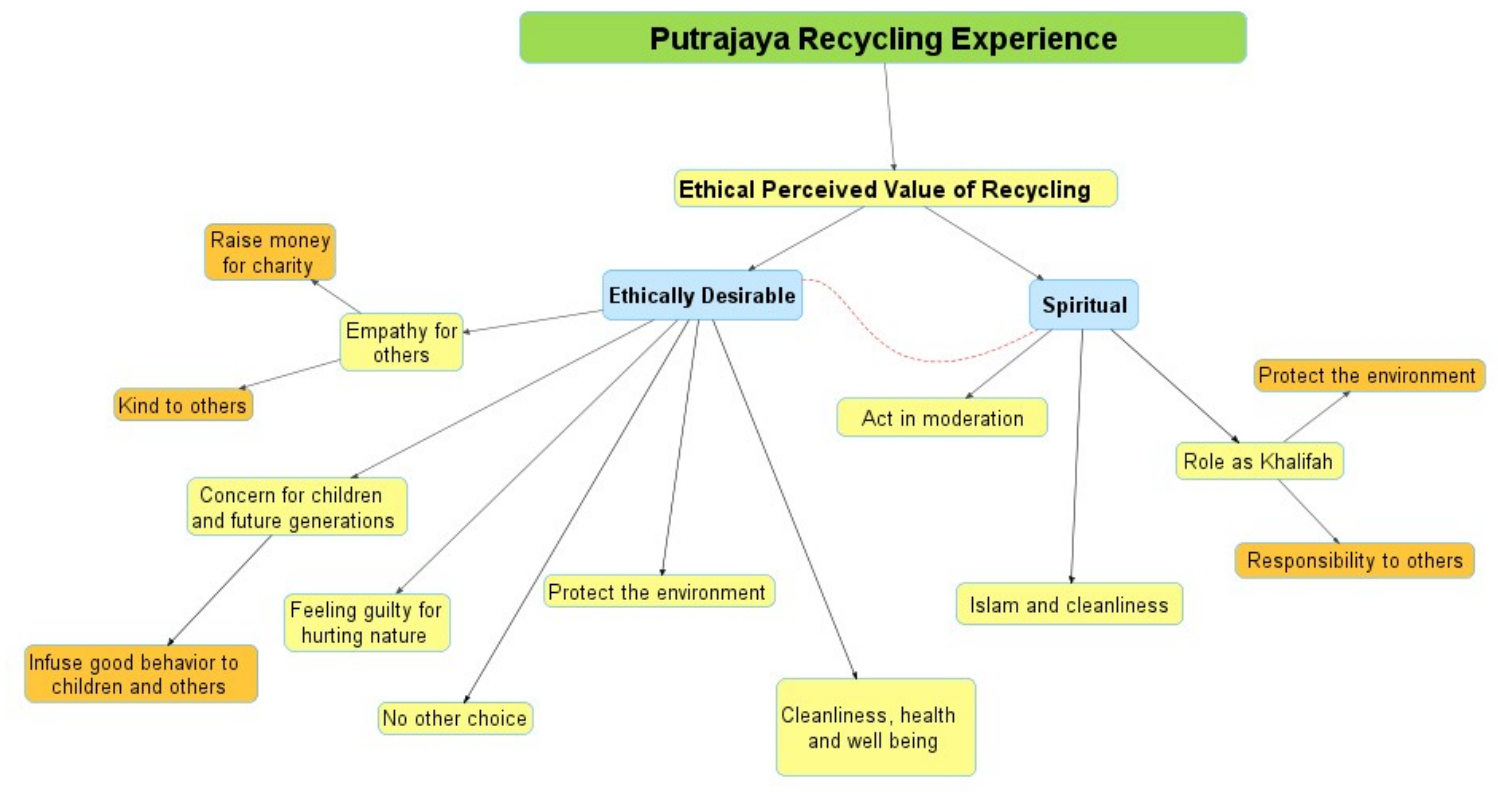

Map 1: Individual's Ethical Perceived Value from Recycling Experience in Putrajaya

EDV taxonomy presented close similarities to several extant studies which relate altruistic, biospheric and self-interest value to environmental behaviour. Unlike others, this study extends further understanding on how self-interest value is portrayed to offer excellent motivational impact on recycling behaviour in Putrajaya. The element of cleanliness, health and well-being are perceived as self-beneficial and self-rewarding; thus, considered as part of motivating factors for individual recycling behaviour. Additionally, the negative impact of environmental degradation convinces recyclers to practice environmental behaviour. 
$\mathrm{SV}$ found is more connected from Islamic values. The ethically driven behaviour practices by recyclers are guided by motives in pursue of Allah's pleasure. The findings presented some connections between both attributes of ethically desirable and spiritual value.

EDV taxonomy are similar to the attributes in SV. 'Empathy for others' in EDV is interrelated to the human role as a khalifah whereby humans are obliged to nurture and maintain good relationship with other humans. Furthermore, ethically desirable behaviours in Islam insist on infusing good values to children, family, neighbours and society including collectivism in maintaining the good welfare of the community. Cleanliness, internal purity and prevention of wasteful behaviours found are among the ethical conducts associated by recyclers in expressing their religious value. As a khalifah humans are the trustees of nature created for the mankind. Consistent with Islamic perspective, religious value should be a wholesome value that promotes ethical behaviours in recycling.

Nevertheless, both value taxonomies reflected different basis of perceived value. The recyclers identified their behaviour directly and indirectly to Islamic perspective. From Putrajaya's perspective, Islamic religious value offers more internal consistency in defining sustainable recycling behaviour among recyclers. Each behaviour is seen as part of ibadah in pursue of Allah's pleasure. One customer shared her recycling experience in preserving the environment. She was sometimes being laughed for using containers at food bazaar; when others thought that she is a 'chronic' recycler, she only cares about her intention to preserve what Allah bestowed upon her.

Map 2 summarizes the reflection of Islamic religious role. However, the study suggested that Islamic religious role is not translated as the mutual perceived value appreciated by all informants. Although Putrajaya is dominated by Muslims, the connection of Islam and environmental behaviour is still minimally understood. As shared by informants 7 and 8:

R7 - I also don't know why, the more we understand religion (relates to preservation of the environment), we became even worst. It's just not working! I mean, the way we act, we didn't actually practice our religion. 
We just understand it on the surface. We still lack the akhlak (ethical behaviour).

R8 - If we compare with Japan, it's a clean country. They have all the systems and techniques in making their country clean. We Muslims, we didn't even separate our organic wastes. We dump everything, food, papers and plastic together. In Japan, they separated everything, it's clean. They are practicing something that we as a Muslim suppose to perform. Arab countries, for instance at their hotels, they throw away food, a lot of wasteful behaviours. The message just doesn't reach the Muslims. We are still clueless about our own religion.

Additionally, when informants 2 and 3 were probed on religion role in their recycling behaviour, both agreed that Islamic religious practice offers limited connection in recycling behaviour. Informat 2 and 3 shared their views:

R3 - It is not about religion. It's about an attitude. Sometimes when they are at home, they know the rules, they don't litter. But when they are outside, they throw rubbish wherever they wish! Rubbish from the car is easily thrown out. It's about an attitude. At school, everybody is taught about civic consciousness. It was taught when we were kids. Look at westerners, they are not Muslim, but they practice recycling. It (recycling) doesn't have connection with religion.

R3 - I think recycling doesn't have connection with religious beliefs. Every religion does not favour wasteful behaviours. 


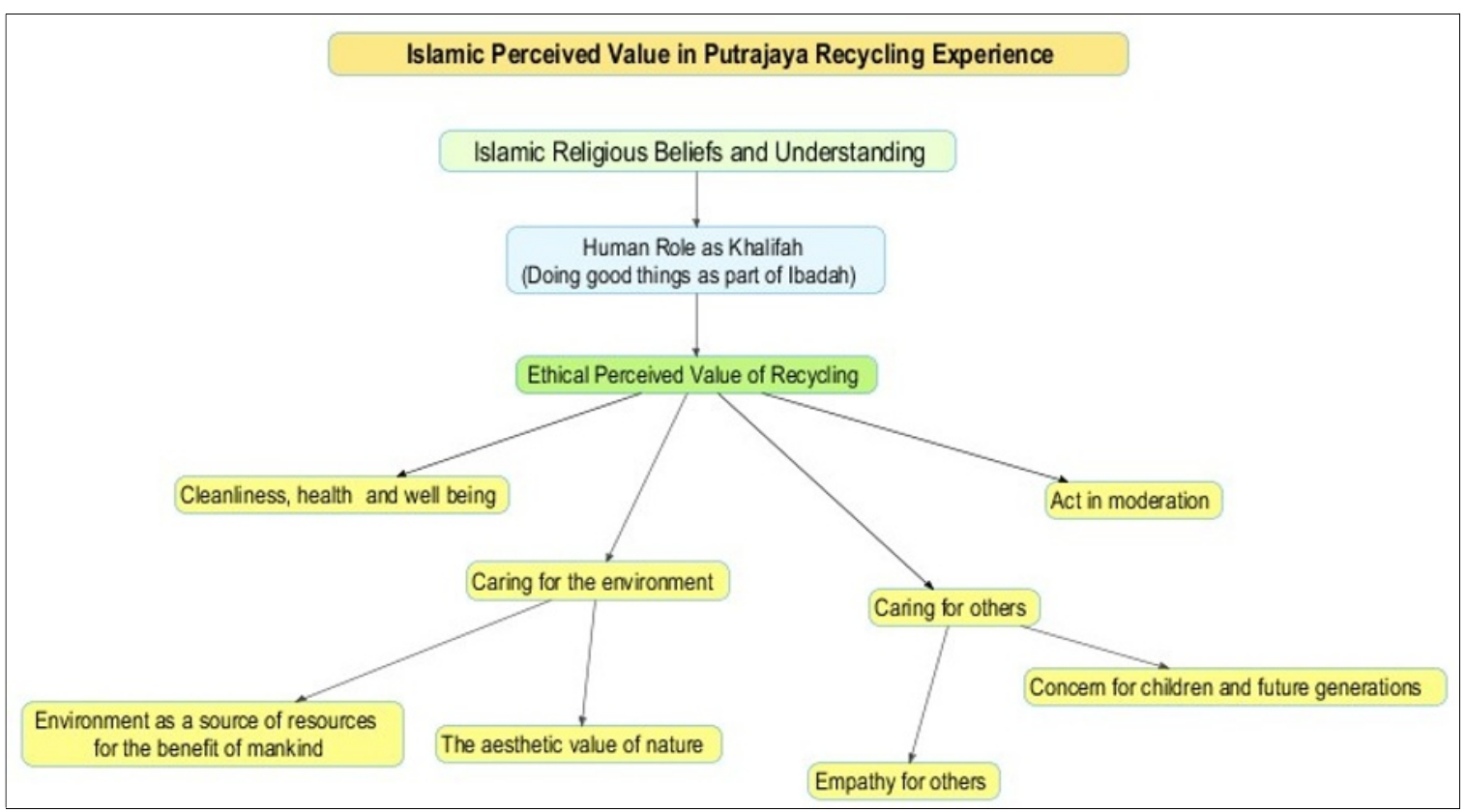

Map 2: The Reflection of Islamic Religious Role in Putrajaya Recycling Experience

\section{Conclusion}

The study aimed to explore and understand the meanings of EPV in Putrajaya recycling experience, induces satisfying experience; thus, sustain recycling behaviour among recyclers. Based on the findings, all were confirmed. From social marketing perspective, the existing knowledge of recycling experience in ECPV context is extended. The understanding of ECPV is hoped to bridge the gap between social marketers, policy makers and the consumers; offering a preliminary guideline to suggest more effective intervention programs, promotions and communication strategies (Ziethaml 1988; Woodruff 1997; Smith and Colgate 2007) to promote sustainable recycling behaviour.

The findings suggest several ethical connections in driving and sustaining recycling behaviour. From the above, ethically desirable behaviours are derived from the affection and empathy for other people, caring for nature and guilt for hurting nature. The threats of nature, urged them to protect themselves. Additionally, the importance of health, cleanliness and well-being are among the important self-interest drivers that motivate and sustain recycling behaviour. The religion role, is prominent in inducing sustainable recycling behaviour. However, a few appreciate it. Though the study is conducted among 
Muslims, there is still lack of understanding on how recycling and preserving the environment are seen as part of Islam.. Fundamental understanding and cultivation of positive core values are required to create the awareness. Programs and communication messages designed to motivate recycling behaviour should emphasize common elements to the society. Thus, there have been limited attempts that explore ECPV from social marketing context, particularly on social participation and recycling experience. The affection and cognition cues defined from ECPV is hoped to relay a more accurate perspective about the consumer segment in Putrajaya.

\section{Acknowledgements}

The authors would like to thank Perbadanan Putrajaya, Alam Flora and Perbadanan Pengurusan Sisa Pepejal dan Pembersihan Awam for their kind assistance throughout the process of data collection. 


\section{References}

Ahmad, A. (2009). Global ethics, environmentally applied: An Islamic view. In K. T. ip, Environmental Ethics: Intercultural Perspectives (pp. 93-114). Amsterdam: Rodopi B.V.

Baharuddin, A. (2012, January 3rd). Sustaining a natural balance: IKIM Views. The Star.

Bamberg, S. \&. (2007). Twenty years after Hines, Hungerford and Tomera: A new meta analysis of psycho-social determinants of pro-environmental behavior. Journal of Environmental Psychology, 27:14-25.

Barr, S. (2007). Factors Influencing Environmental Attitudes and Behaviors : A U.K.Case Study of Household Waste Management. Environment and Behaviour , 39(4):465-473.

Chawla, L. (1999). Life Path Into Effective Environmental Action. The Journal of Environmental Education, 31(1):15-26.

Creswell, J. W. (2007). Qualitative Inquiry and Research Design. New Delhi: Sage Publications.

De Young, R. (1986). Some psychological aspects of recycling: The structure of conservation satisfactions. Environment and Behaviour, 18(4):435-449.

De Young, R. (2011). Slow wins: Patience, preserverance and behavior change. Carbon Management, 2(6):607-611.

De Young, R. (2013). Environmental psychology overview. In S. R. Klein, Green Organizations: Driving Change with 10 Psychology (pp. 22-45.). New York : Routledge Academic.

Dietz, T.; Fitzgerald, A. and Shwom, R. (2005). Environmental Values. Annual Review Environmental Resources, 30:335-372.

Gallarza, M.; Saura, I. G.; Holbrook, M. (2011). The value of value: Further excursions on the meaning and role of customer value. Journal of Consumer Behavior, 10: 179-191.

Guerin, D., Crete, J., \& Mercier, J. (2001). A Multilevel Analysis of the Determinants of Recycling Behavior in the European Countries. Social Science Research , 30, 195-218.

Halvorsen, B. (2012). Effects of norms and policy incentives on household recycling:An international comparison. Resources, Conservation and Recycling, 67:18-26.

Holbrook, M. (1999). Consumer Value: A Framework for Analysis and Research. New York: Routledge. 
Holbrook, M. B. (2006). Consumption experience, customer value and subjective personal introspection: An illustrative photographic essay. Journal of Business Research, 59:714725.

Khalid, F. M. (2002). Islam and The Environment. In T. Munn, Encyclopedia of Global Environmental Change (pp. 332-339). Chichester: John Wiley and Sons.

Mashitoh Yaacob. (2009). The influence of contextual aspect of New Zealand muslim males' environmentally ethical behaviour. New Zealand: The University of Waikato.

Milfont, T.L. and Duckitt, J. . (2010). The Environmental Attitudes Inventory: A Valid and Reliable Measure to Asess the Structure of Environmental Attitudes . Journal of Environmental Psychology, 30:80-94.

Mohamad, Z. F.;Idris, N. ; Baharuddin A.;Muhammad, A. ; Nik Sulaiman, N.M. (2012). The role of religious community in recycling: Empirical insights from Malaysia. Resources, Conservation and Recycling, 58:143-151.

Mohamad, Z.F.; Idris, N. and Baharuddin, A. (2011). Religion and Waste. Waste Management, 31: 1905-1906.

Mortazavi, S. (August 2004). Islamic economics: A solution for environmental protection. Trade, Growth and the Environment. UK: Oxford University.

Nordlund, A. M. and Garvill, J. (2002). Value Structures Behind Proenvironmental Behaviour. Environment and Behavior, 34(6): 740-756.

NST. (2012, January 15). Putrajaya retains top spot in recycling. New Straits Times.

Osbaldiston, R. and Schott, J. P. . (2012). Environmental Sustainability and Behavioral Science: Meta Analysis of Pro-Environmental Behavior Experiments. Environment and Behavior, 44(2):257-299.

Ozdemir, I. (2003). Toward an understanding of environmental ethics from a Quranic Perspective. In R. Foltz, \& F. a. Denny, Islam and Ecology: A Bestowed Thrust (pp. 3-29). Cambridge: Harvard University Press.

Prestin, A.; Pearce. K.E. (2010). We care a lot: Formative research for a social marketing campaign to promote school-based recycling. Conservation and Recycling, 54(11):10171026.

Rokeach, M. (1973). The Nature of Human Values. New York: The Free Press. 
Saphores, J.M.; Ogunseitan, O. A. and Shapiro,A.A. (2012). Willingness to engage in a proenvironmental behavior: An analysis of e-waste recycling based on a national survey of U.S. households. Resources, Conservation and Recycling, 60:49-63.

Schultz, P. W. (2001). The structure of environmental concern: concern for self, other people and the biosphere. Journal of Environmental Psychology, 21:327-339.

Schultz, P.W. and Zelenzy, L. (1999). Values as Predictors of Environmental Attitudes: Evidence for Consistency Across 14 Countries. Journal of Environmental Psychology, 19:255-265.

Schwartz, H. S. (2012). An Overview of the Schwartz Theory of Basic Values. Psychology and Culture, http://dx.doi.org/10.9707/2307-0919.1116.

Schwartz, S. (1977). Normative Influence in Altruism. In L. Berkowitz, Advances in Experimental Social Psychology (pp. 221-279). New York: Academic.

Smith, J.B. \& Colgate, M. (2007). Customer Value Creation: A Practical Framework. Journal of Marketing Theory and Practice, 15(1): 7-23.

Stern, P. (2000). Towards a Coherent Theory of Environmentally Significant Behavior. Journal of Social Issues, 50:65-84.

Stern, P. (2005). Understanding Individuals' Environmentally Significant Behavior. ELR News and Analysis, 35:85-90.

Stern, P. C. \& Dietz, T. (1994). The value basis of environmental concern. Journal of Social Issues, 50:65-84.

Tang, Z.;Chen, X.; Luo, J. (2011). Determining Socio-Psychological Drivers for Rural Household Recycling Behavior in Developing Countries : A Case Study From Wugan, Hunan, China. Environment and Behavior , 43(6): 848-877.

Thompson, S. C. G. \& Barton, M.A. . (1994). Ecocentric and Anthropocentric Attitudes Towards the Environment. Journal of Environmental Psychology, 14:149-157.

Torgler, A., Valinas, M., \& Macintyre, A. (2008). Environmental Participation and. Climate Change Modelling and Policy. Milan: Fondazione Eni Enrico Mattei.

Woodall, T. (2003). Conceptualizing 'value for the customer': An attributional, structural and dispositional analysis. Journal of the Academy of Marketing Science, 12.

Woodruff, R. (1997). Customer value: The next source for competitive advantage. Journal of Academy of Marketing Science, 25(2):139-153.

Ziethaml, V. A. (1988). Consumer perceptions of price quality and value: A means-end model and synthesis of evidence. Journal of Marketing, 2-22. 